\title{
МІКАЛАЙ АНТРОПАЎ
}

\section{СТАРОНКА 3 ГІСТОРЫ БЕЛАРУСКАЙ ЭТЫМАЛОГІ: ПРАСПЕКТ РЭЙНГОЛЬДА КРАЎЧУКА}

CobIss: 1.01

\section{Stran iz zgodovine beloruske etimologije: koncept Rejngolda Kravčuka}

Članek je posvečen malo znanemu detajlu izdelave Etimološkega slovarja beloruskega jezika, namreč neobjavljenemu konceptu tega slovarja, kakršnega je v začetku sedemdesetih let 20. stoletja napisal eden od avtorjev prvih zvezkov. Analizirajo se kompozicija, predložena metodologija in drugi detajli glede na dejansko izvedbo.

Ključne besede: etimologija, slovarji, beloruščina, zgodovina

\section{From the history of Belarusian etymology: Rheingold Kravchuk's prospectus}

This article discusses a relatively unknown detail in the history of creating the Etymological Dictionary of Belarusian; namely the prospectus for this dictionary, set up by one the authors of the first volumes in the early 1970s. It analyses the composition of the prospectus, the methodology suggested for the dictionary, and other details with regard to how this process was finally realized in a real-life context.

Keywords: etymology, dictionaries, Belarusian, history

У гісторыі стварэння “Этымалагічнага слоўніка беларускай мовы” (ЭСБМ) ёсць адна дасюль малавядомая старонка, звязаная з імем знанага ў 50-80 гады ўкраінскага і беларускага славіста і этымолага, аднаго з аўтараў чатыpox першых тамоў ЭСБМ Рэйнгольда Ўладзіміравіча Краўчука.

Біяграфічныя звесткі аб ім наступныя.1 Будучы вучоны-мовавед нарадзіўся 26 снежня 1929 г. у цэнтры Ўсходняй Сібіры, менавіта Канску Краснаярскага краю, аднак яшчэ да вайны сям'я пераехала ва Ўкраіну, бо ў аўтабіяграфіi Р. Краўчук піша, што пайшоў у школу ў Харкаве ў 1937 г., а атрымаў сярэднюю адукацыю у Львове ў 1947 г. (ЛД: 8). У тым самым годзе ён паступіў у Львоўскі універсітэт імя Івана Франка на славянскае аддзяленне філалагічнага факультэта, які праз пяць год закончыў па спецыяльнасці “славянскае мовазнаўства (чэшская мова)". У кастрычніку 1952 г. Р. Краўчук паступіў у аспірантуру Інстытута мовазнаўства АН УССР па

1 Іх крыніцамі з'яўляюцца два біяграфічныя артыкулы, гл. (Институт мовознавства 2005: 470; Лучыц-Федарэц 2010: 153-154), прычым абодва, у сваю чаргу, грунтуюцца на аўтабіяграфіях Р. Краўчука з яго асабістых спраў у Інстытуце мовазнаўства імя А. А. Патабні НАН Украіны (Кіеў) і НАН Беларусі (Мінск; гл.: ЛД). 
спецыяльнасці “Параўнальная граматыка славянских моў”, дзе пад кіраўніцтвам тагачаснага дырэктара Інстытута акадэміка Леаніда Булахоўскага ён набыў грунтоўную філалагічную падрыхтоўку, атрымаў фундаментальныя веды па шэрагу праблем параўнальнай граматыкі славянскіх моў, адмыслова ў галіне словаўтварэння, якім потым займаўся на працягу ўсёй сваёй навуковай дзейнасці, а таксама працягнуў вывучэнне славянскіх і еўрапейскіх моў.2 Усё гэта дазволіла яму падрыхтаваць і паспяхова абараніць у маі 1959 г. кандыдацкую дысертацыю ў галіне багемістыкі “История суффиксов существительных в чешском языке. Суффиксы с основным -к- (на материале памятников XIV-XVI вв.)", прысвечаную актуальнай праблеме чэшскай гістарычнай дэрываталогіi (Кравчук 1958а; гл. таксама сціслы варыянт працы ў брашуры: Кравчук 1958б).

Пасля заканчэння аспірантуры Р. Краўчук плённа працуе ў аддзеле агульнага і славянскага мовазнаўства, дзе ў 1955-1960 гг. выконвае частку “Славянскія чаргаванні галосных" агульнай планавай тэмы “Параўнальная граматыка славянскіх моў”, якая завяршылася выданнем у 1966 г. добра вядомай адмыслоўцам, знакавай для таго часу калектыўнай манаграфіi “Вступ до порівняльно-історичного вивчення слов'янських мов”. 3 Якраз гэтымі гадамі датуецца пачатак яго зацікаўленасці праблемамі славянскай, у прыватнасці ўкраінскай, этымалогіi, сведчаннем чаго з'яўляюцца два яго першых адмыслова этымалагічных артыкулы (Кравчук 1955; 1957). Аднак гэты інтарэс меў яшчэ і “планавы” характар, пра што сведчаць аўтары ўкраінскага этымалагічнага слоўніка Таццяна Лукінова і Рыгор Піўтарак:

Після завершення роботи над "Вступом до порівняльно-історичного вивчення слов'янських мов” перед славістами Інституту постала давно назріла проблема створення етимологічного словника української мови. Щоправда, над цією проблемою наприкінці 50-х років працював науковий співробітник відділу загального та слов'янського мовознавства Р. В. Кравчук. Ще в 1958 р. він виконував планову тему “Вступ до этимологічних досліджень у галузі слов'янських мов”. Згодом він підготував два випуски “Етимологічного словника української мови”, які не були опубліковані.4 Стала очевидною потреба в академічному етимологічному словни-

2 У “Асабістым лістку па ўліку кадраў”, які ён запоўніў у Мінску ў верасні 1963 г., Р. Краўчук пералічае мовы, якімі валодае: нямецкая, французская, італьянская, англійская; чэшская, польская, сербскахарвацкая, руская, украінская (ЛД: 4). Літаральна адразу пасля пераезду ў Мінск ён авалодвае беларускай мовай, а выключнай дакладнасці спасылкі ў яго працах больш позняга часу дазваляюць далучыць да пазначанага спісу па меншай меры таксама літоўскую, румынскую і венгерскую мовы.

3 Аднак прозвішча Р. Краўчука сярод яе аўтараў няма, гл. у прадмове да (Вступ 1966: 3-5).

4 Пазней гэтыя матэрыялы былі выкарыстаны (трэба аднак думаць, усё ж такі часткова) у незвычайна вялікай нават для вядучага савецкага лінгвістычнага перыёдыка маскоўскага часопіса "Вопросы языкознания" грунтоўнай рэцэнзіі аўтара на выдадзеныя ў Вінніпегу (Канада) першыя пяць выпускаў этымалагічнага слоўніка ўкраінскай мовы Яраслава-Багдана Рудніцкага, гл. (Кравчук 1968) і часткова ў працы над “Этымалагічным слоўнікам беларускай мовы" (Лучыц-Федарэц 2010: 154). 
кові великого обсягу, підготовленому потужним авторським колективом (Лукінова - Півторак 2005: 87).

Аднак значна раней, яшчэ ў 1961 г., пра ўкраінскі этымалагічны слоўнік Р. Краўчука пісаў Алег Трубачоў:

Так, можно не колеблясь назвать удачным первый выпуск «Краткого этимологического словаря украинского языка» $(A-$ безбеш), подготовленный к печати Р. В. Кравчуком (Трубачев 2004а: 26), -

а ў 1978 г. ён жа распавёў пра тое ж крыху падрабязней:

Несколько раньше, в самом начале 1960-х гг., в Киеве работал над украинским этимологическим словарем в качестве индивидуальной темы Р. В. Кравчук (в настоящее время - в Минске); я знакомился тогда с его 1-м выпуском $(A-б е з б е ш)$ как рецензент. Работа, однако, не получила продолжения (Трубачев 2004б: 372-373).

Такім чынам, відавочна, што ў пачатку 60-х гадоў Р. Краўчук быў ужо ў высокай ступені падрыхтаваным этымолагам з шырокімі фундаментальнымі ведамі ў гэтай вобласці, 5 пра што слушна сведчыць яго мінскі калега і сябра6 Іван Лучыц-Федарэц:

Даследчык валодаў усімі якасцямі, каб паспяхова працаваць у этымалогіi - адной 3 самых складаных галін лінгвістыкі: вялікай эрудыцыяй, магутнай інтуіцыяй, назіральнасцю, крытычным падыходам да сваіх і чужых версій, цвярозым разуменнем магчымасцей этымалагічнага аналізу, добрым веданнем славянскай дыялектнай лексікі (Лучыц-Федарэц 2010: 154).

Аднак у аўтарскі калектыў “Етимологічного словника української мови” (ЕСУМ) Р. Краўчук не ўвайшоў, падставай для чаго была, не выключана, уласная пазіцыя першага аўтара ўкраінскага этымалагічнага слоўніка, грунтоўныя распрацоўкі якога не толькі не былі ўлічаны (за выключэннем апублікаваных, на якія ёсць спасылкі ў асобных артыкулах), а папросту адкінуты. ${ }^{7}$ Больш за тое, складаныя адносіны 3 кіраўніцтвам аддзела і інстытута (пасля Л. Булахоўскага з 1961 г. яго ўзначальваў І. Білодід), абставіны асабістага характару і адначасова запрашэнне дырэктара беларускага акадэмічнага Інстытута мовазнаўства Міхаіла Судніка8 паспрыялі неўзабаве яго пераезду ўвосень 1963 г. у Мінск, дзе ў аддзеле славянскага і тэарэтычнага мовазнаўства ён працаваў да свайго заўчаснага сыходу з жыцця ў маі 1989 г.

5 Дарэчы, ускосным сведчаннем гэтага з'яўляецца таксама мэтанакіраванае вывучэнне Р. Краўчуком гісторыі славянскага мовазнаўства, якое ўвасобілася ў адмысловай манаграфіі, дзе падаюцца звесткі амаль пра сто асоб - выдатных усходнеславянскіх, савецкіх і замежных моваведаў і іх асноўныя працы (Кравчук 1961).

6 Абодвух вучоных яднала, апрача сумеснай працы ў адным калектыве, памяць пра агульную alma mater - Львоўскі ўніверсітэт, у якім І. Лучыц-Федарэц таксама скончыў багемістыку на філалагічным факультэце, але на восем год пазней, у 1960 г.

7 У сувязі з гэтым, нельга не адзначыць, што прозвішча Р. Краўчука ніяк не уцзгадваецца ў прадмове і даведачных матэрыялах да 1-га тома ЕСУМ.

8 Наколькі вядома, па рэкамендацыі маскоўскіх славістаў, у першую чаргу Мікіты Талстога. 
Трэба адзначыць, што ў Мінск Р. Краўчук прыехаў менавіта для працы над ЭСБМ,9 таму калі распачаліся работы над стварэннем рэестра беларускага слоўніка, назапашваннем матэрыялаў для яго, ужо дастаткова спрактыкаваны вучоны-славіст падрыхтаваў рукапіс праспекта слоўніка, які таксама не быў апублікаваны. Хаця гэты праспект час ад часу ўзгадваўся тымі, хто пісаў пра гісторыю стварэння ЭСБМ, гл., напрыклад (Антропов 2010: 34; Лучыц-Федарэц 2010: 154 і інш.), аднак ніякіх змястоўных звестак пра яго аўтары не прыводзілі з прычыны адсутнасці ў іх тэксту. Між тым, гаворка ідзе пра даволі аб’ёмістую працу, аб чым піша I. Лучыц-Федарэц:

У самым пачатку, калі ў аддзеле ішла работа па назапашванні лексікалагічнага $\mathrm{i}$ этнаграфічнага матэрыялу для слоўніка, Р. У. Краўчук стварыў рукапіс памерам 5 аўт. арк. "Праблематыка беларускага этымалагічнага слоўніка (агульныя палажэнні, праспект, пробныя артыкулы)" (Лучыц-Федарэц 2010: 154.)

Гэтае сведчанне таксама мае грунтам уласнаручную прыпіску Р. Краўчука ад 18.12.1985 г. да спісу яго навуковых прац у “Асабістай справе”, які быў складзены 9.01.1985 г. (ЛД: 24-30), дзе, на жаль, замест года стварэння праспекта пазначаецца няпэўнае “в свое время”, затое ў дужках падаецца яго дакладны аб’ём - “120 стр. машинописи” (ЛД: 30).

Стваралася ўражанне, што гэты рукапіс назаўсёды страчаны, аднак, на шчасце, не так даўно ён знайшоўся ў асабістым архіве Генадзя Цыхуна - старэйшага на сённяшні час аўтара і цяперашняга галоўнага рэдактара ЭСБМ. Рукапіс уяўляе сабой машынапісны тэкст (3 ці 4 адбітак) без загалоўка на 71 старонцы, 10 перадрукаваны, верагодна, сакратаркай сектара, і не вычытаны, бо ўтрымлівае дастатковую колькасць абдруковак. Рукой Г. Цыхуна на першым лісце пазначана: "Праспект Этымалагічнага слоўніка беларускай мовы (апошні варыянт. Укл. Р. У. Краўчук, В. У. Мартынаў - рэд.)”. Далей ідзе старонка “Ад рэдактара”, г. зн. Віктара Мартынава:

Гэты праспект беларускага этымалагічнага слоўніка складзены з як мага больш поўным улікам агульных і своеасаблівых задач такіх выданняў. Ён строга вытрыманы ў духу старай кампаратывістыкі і этымалагічнай практыкі. Рэдактар падзяляе думку аўтара аб тым, што ў этымалагічным слоўніку асобнай славянскай мовы немэтазгодна правяраць эфектыўнасць новых методык і прыводзіць занадта глыбокія рэканструкцыі.

9 Больш за тое, для кіраўніцтва планавай тэмай, звязанай з падрыхтоўкай слоўніка, пра што сведчыць загад па Інстытуце мовазнаўства ад 5 студзеня 1973 г., дзе чытаем: «[...] ў свой час ён быў вызвалены ад кіраўніцтва тэмай “Этымалагічны слоўнік беларускай мовы”» (ЛД: 37). Праўда, дакумент аб прызначэнні яго кіраўніком пакуль што аўтарам артыкула не знойдзены.

10 Атрымліваецца, што перад намі няпоўны тэкст, у якім адстутнічае значная частка на 50 старонак, што свечыць на карысць існавання ледзь не ўдвая больш поўнага варыянта, не выключана, 3 большай колькасцю пробных артыкулаў. 3 другога боку, гаворка магла таксама ісці пра ўласна рукап іс, а не машынапісную перадрукоўку. 
Асноўнай мэтай этымалагічнага слоўніка беларускай мовы з'яўляецца вызначэнне месца беларускай лексікі сярод іншай славянскай, размежаванасці архаізмаў і інавацый, выяўленне крыніц старых запазычанняў і пранікненняў.

Раздзел "Пытанні беларускай этымалогіi і балта-славянская праблема" напісаны рэдактарам.

I загаловак “Ад рэдактара”, і змест тэксту ўказваюць, несумненна, на падрыхтоўку рукапісу да выдання ў якасці пробнага выпуску ЭСБМ, хаця ніякіх звестак пра тое, што ён рыхтаваўся, усё ж такі няма.

Важным пытаннем з'ўляецца атрыбуцыя рукапісу, які трэба аднесці да часу пазней за 1968 г., бо якраз гэтым годам датуецца шэраг спасылак: у прыватнасці, у частках, напісаных Р. Краўчуком, iх 4, а ў мартынаўскай - яшчэ дзве. Але 3 яшчэ большай верагоднасцю раздзелы, напісаныя Р. Краўчуком, трэба датаваць 1968-1969 гг., а частку В. Мартынава - 1970-1971 гг.,11 бо апошняя спасылка ў ім падаецца на артыкул М. Талстога "Об одном балтизме в восточнославянских диалектах - пелька” са зборніка “Этымалогія-1967”, які выйшаў у самым канцы 1969 г. ці нават ў пачатку 1970-га, таму што ў выходных даных пазначана, што ён падпісаны да друку 24.11.1969 г.

Частак, напісаных Р. Краўчуком, тры: “І.12 Агульныя палажэнні" (c. 4-31), "Спецыяльныя задачы беларускага этымалагічнага слоўніка" (c. 31-40), "Пробныя артыкулы” (с. 63-71). Таксама ў раздзеле “Спасылкі і заўвагі” пазіцыі 1-70 (с. 54-59) звязаны з першымі дзвюма часткамі. Раздзел “Пытанні беларускай этымалогіі і балта-славянская праблема" (с. 40-53), да якога прыведзены спасылкі 71-83 (с. 59-62), як ужо ўзгадвалася вышэй, напісаны В. Мартынавым.

Часткі рукапісу “Агульныя палажэнні” і “Спецыяльныя задачы беларускага этымалагічнага слоўніка” фактычна не структураваны, уяўляюць сабой “гладкі” тэкст, аднак вылучэнне яго змястоўных складнікаў, зразумела, магчыма. У першай падрабязна разглядаюцца найбольш агульныя прынцыпы этымалагізавання славянскай лексікі на ўсіх узроўнях моўнай сістэмы, г. зн. фанетычным, марфалагічным, словаўтваральным i, часткова, семантычным, прычым апошні спецыяльна на вылучаецца,13 аднак экспліцытна прысутнічае ва ўсіх частках. Канстатуючы ў кароткіх уводзінах, што “беларуская

11 I адназначна не пазней за 1973 г., таму што ні ў тэксце (у прыватнасці, разважаннях адносна праславянскага словаўтварэння), ні ў літаратуры не узггадваецца "Etymologický slovník slovanských jazyků. Slova gramatická a zájmena” Францішка Копечнага, першы выпуск якога выйшаў у Празе акурат у 1973 г. Ускосным сведчаннем гэтай даты можна лічыць і тое, што часткі тэксту В. Мартынава тэкстуальна супадаюць $з$ уводным раздзелам яго брашуры з дакладам на VII Міжнародным з'ездзе славістаў (Варшава, 1973 г.), які рыхтаваўся ў 1972 - пачатку 1973 гг., гл. (Мартынов 1973).

12 Пранумараваны толькі гэты раздзел.

13 За выключэннем аднаго абзаца 3 крытыкай перабольшвання ролі семантыкі (у прыватнасці, В. Махэкам) у этымалагічнх даследаваннях (с. 30). 
мова - адна з параўнальна нямногіх славянскіх моў, якія не маюць этымалагічнага слоўніка", Р. Краўчук слушна заўважае:

Гэта варта жалю, бо беларуская лексіка, не гаворачы ўжо пра вялікую карысць ад увядзення яе ў лінгвістычную практыку, мае мноства элементаў, улік якіх у славянскіх этымалогіях вельмі і вельмі пажаданы (с. 4), -

і прыводзіць шэраг пацвярджаючых тэзіс прыкладаў, у прыватнасці беларускія кантынуанты прасл. *govedo, *osa 'асіна' і інш. На думку аўтара, беларускі матэрыял дазволіць “зусім па новаму зірнуць на адносіны паміж роднаснымі мовамі” (с. 5) і пры гэтым быць вельмі запатрабаваным пры абгрунтаванні праславянскіх дыялектызмаў.14 Дарэчы, пытанні дыялектнага члянення праславянскай мовы $з$ прыцягненнем этымалагічнай фактаграфіi займаюць у праспекце некалькі старонак (гл., у прыватнасці, с. 9-17).

Далей аўтар спыняецца на наступных пытаннях, падрабязна раскрываючы іх змест:

1. Агульная задачы этымалагічнага слоўніка. Задачы этымалагічнага слоўніка асобнай славянскай мовы; 2. Максімальны рэестр як адлюстраванне задач сучаснага этымалагічнага слоўніка асобнай славянскай мовы (с. 7).

Зразумела, большасць пазіцый, датычных агульна-этымалагічнай праблематыкі, пра якія піша Р. Краўчук, і высноў, да якіх ён прыходзіць, добра вядомыя этымолагам-славістам (ад часу стварэння праспекта прайшло усё ж такі ледзь не паўстагоддзя) і неаднаразова абмяркоўваліся ў літаратуры, таму сэнсу іх пераказваць няма.15 Аднак на асобных момантах спыніцца ўсё ж такі варта, асабліва з улікам іх наяўнасці/адсутнасці ў прадмове да 1-га тома ЭСБМ (Мартынаў 1978) і рэальнай практыкі працы над слоўнікам.

Адным з такіх момантаў з'яўляецца думка аб эўрыстычнай каштоўнасці этымалагічнага слоўніка, што ў высокай ступені актуальна і ў наш час:
Зараз этымалагічны слоўнік стаў, ці па крайняй меры становіцца, формай даследа- вання лексікі. Гэта высоўвае перад складальнікам даволі шырокія задачы 3 новымі элементамі, што патрабуе ад яго не толькі шмат сіл, добрасумленнай пільнасці, уседлівасці, але і грунтоўнай кампаратывісцкай падрыхтоукі, пры абавязковым уменні займацца філалагічнымі даследаваннямі. Пра тое, што сучасны [стан] эты- малагічнага слоўніка патрабуе намнога болей часу, - можна і не гаварыць (с. 8).

14 Крыху пазней, у 1978 г., аналагічныя думкі выказваў і А. М. Трубачоў, параўн. “Срединное положение белорусского языка, напоминающее до известной степени положение словацкого языка, представляется во многих отношениях уникальным, достаточно вспомнить, с одной стороны, продвинутую фонетическую эволюцию белорусского языка и, с другой стороны, - местами довольно архаический словарный состав и соответствующее ему словообразование. Все это чем дальше, тем больше приковывает внимание славистов к белорусской лексике и этимологии" (Трубачев 2004б: 365).

15 Разам з тым, публікацыя ўсяго тэксту, напрыклад, у якасці дадатку да аднаго з чарговых тамоў ЭСБМ, безумоўна, цалкам пажаданая. 
Даволі значнае месца ў першай частцы займае пытанне рэестра этымалагічнага слоўніка, што для ЭСБМ заўсёды было і па-ранейшаму застаецца выключна актуальным. Р. Краўчук адзначае:

Задачы сучаснага этымалагічнага слоўніка патрабуюць максімальнага рэестра. Тры асноўныя крыніцы рэестра [...] - лексіка літаратурнай мовы, дыялектная лексіка і лексіка помнікаў - адлюстроўваюць прызначэнне сучаснага этымалагічнага слоўніка асобнай мовы як фундаментальнага даследавання лінгвістычнага і культурна-гістарычнага характару (с. 18).

Абмяркоўваючы далей дыялектны матэрыял, аўтар пераканаўча разважае пра немагчымасць падзяляць дыялектызмы на “шырокія i” “вузкія”, таму што і адны, і другія заслугоўваюць свайго месца ў этымалагічным слоўніку, 16 асабліва ўлічыўшы, што ў апошнім пласце лексікі “не так ужо рэдка сустракаюцца праславянскія архаізмы"17 (там жа).

Таксама даволі падрабязна аўтар вядзе гаворку пра ўключэнне ў рэестр лексікі помнікаў, і яго меркаванні на гэты конт заслугоўваць, безумоўна, ўвагі, параўн., напрыклад, наступнае:

Няма ніякіх падстаў рабіць адбор лексікі помнікаў і па якіх-небудзь іншых адзнаках, напрыклад, выкідаць 3 рэестра словы, якія ў мінулым жылі ў мове толькі кароткі час.Няцяжка давесці, што і гэтыя знікшыя словы варты ўвагі калі не моваведа, дык гісторыка, археолага, фалькларыста, гісторыка літаратуры, этнографа. Нельга забываць, што этымалагічны слоўнік сумяшчае вырашэнне чыста лінгвістычных праблем з зацікаўленасцю знешняй гісторыяй мовы, куды ўваходзіць вельмі шырокае кола пытанняў, якія чакаюць адказаў (с. 27).

Аднак пры ўсёй слушнасці падыходаў Р. Краўчука да моўнага матэрыялу помнікаў, рэалізаваць іх на практыцы было б проста немагчыма з-за істотнага пашырэння аб’ёму слоўніка, таму лексіка помнікаў у якасці за гало вач н ы х слоў (у іншых выпадках яе ўлік - рэч звычайная) уключаецца ў ЭСБМ у выключных выпадках і фактычна толькі тады, калі хаця якія сляды архаізмаў і гістарызмаў магчыма адшукаць у іншых пластах беларускай лексікі.

Ніжэй аўтар яшчэ раз звяртаецца да пытання стварэння рэестра этымалагічнага слоўніка, менавіта да “найбольш цяжкай справы” вызначэння яго аб’ёму:

Той, хто знаёмы $з$ этымалагічнай працай, ведае, што рэестр - гэта ахілесава пята ўсіх этымалагічных слоўнікаў. Няма, відаць, ніводнага этымалагічнага слоўніка, у якім першапачатковы прынцып выбару слоў быў бы праведзены паслядоўна. Нам здаецца, што складанне “жалезнага" папярэдняга спісу слоў, якія павінны ўвайсці ў

16 Ніжэй аўтар слушна і празорліва заўважае: “Тлумачэнне вялікай колькасці дыялектызмаў вельмі замарудзіць працу над слоўнікам, але, трэба спадзявацца, затрачаныя намаганні не будуць дарэмнымі і прынясуць вялікую карысць” (с. 26).

17 Практыка працы над ЭСБМ адназначна пацвярджае гэта меркаванне, гл., у прыватнасці, толькі артыкулы аўтараў ЭСБМ па дакладах на спецылізаванай этымалагічнай канферэнцы ў Любляне (Антропаў 2012; Цыхун 2012). 
будучы этымалагічны слоўнік, - справа даволі нерэальная. [...] Дыяпазон слоўніка мае быць вызначаны загадзя, але рэестр павінны насіць папярэдні характар, г. зн., што абавязкова трэба прадугледжваць магчымасць расшырэння рэестра ў працэсе работы... (с. 25).

Усё гэта ўяўляецца цалкам разумным, але ў практыцы работы над ЭСБМ, на жаль, ідэя нават папярэдняга рэестра не была рэалізавана, і асобныя аўтары складалі яго менавіта ў працэсе работы над сваімі літарамі. Гэта прыводзіла, зразумела, і да пропускаў актуальных для слоўніка найменняў, i да ўключэння (у рэдкіх, бясспрэчна, выпадках) слоў яўна залішніх, не ўласцівых беларускай мове. 18

Асобнае месца займае ў тэксце пытанне прынцыпаў пабудовы слоўнікавага артыкула, і першае месца тут Р. Краўчук адводзіць індаеўрапейскім рэканструкцыям, у фанетычным складніку якіх ён прапануе “абапірацца на канцэпцыі Бругмана - Хірта - Мейе” (с. 21), што ў асноўным супадае з практыкай стварэння этымалагічных слоўнікаў індаеўрапейскіх моў другой паловы мінулага стагоддзя. Цалкам слушныя высновы тычацца межаў рэканструкцый:

...на пытанне: да якой мяжы даводзяцца ў этымалагічным слоўніку беларускай мовы індаеўрапейскія рэканструкцыі? - можна адказаць: як правіла, да мяжы, якая дазваляе [3]аставацца на глебе рэальнасці. Гіпотэзы і дапушчэнні, якія адносяцца да рэканструкцый ужо ў рамках праіндаеўрапейскага, прыцягваюцца ў якасці карысных дапаўненняў, калі ў іх няма недаказальных думак і калі яны грунтуюцца на правераных практыкай гукавых карэспандэнцыях і праўдападобнай марфалагічнай будове індаеўрапейскай мовы. Карацей кажучы, асновай для дапушчэнняў павінны служыць эмпірычныя назіранні, а не дэдуктыўныя збудаванні (с. 21).

Трэба адзначыць, што аўтары ЭСБМ прытрымліваліся менавіта такога падыходу толькі ў асобных, зусім не частых выпадках, таму што і раней, у тамах 1-8 (1978-1993 гг.), глыбіня рэканструкцыі рэдка сягала ніжэй па часавай шкале за праславянскую мову, а ў новай серыі, распачатай 9-м томам (2004 г.), гэта з’яўляецца метадалагічным падмуркам пры распрацоўцы асобных артыкулаў.

Тое ж тычыцца паўнаты адлюстравання бібліяграфічных звестак, якія, на думку Р. Краўчука, “павінны быць максімальна поўнымі, амаль вычарпальнымі” (с. 22). Метадалагічнае патрабаванне падобнай паўнаты паслядоўна рэалізуецца ў ЭСБМ толькі ў адносінах да літаратуры (іншы раз нават навукова-папулярнага кшталту), дзе ёсць згадкі пра этымалагізуемае слова.

Вылучаны раздзел, датычны этымалагічных даведак і звязанай $з$ імі бібліяграфіi, завяршаецца абзацам, які маніфестуе прынцыповую пазіцыю аўтара:

18 Гл., напрыклад, артыкул “Ігра" аўтарства Н. Івашынай у 3-м томе, дзе няма н і в о дн а й спасылкі на беларускую крыніцу. 
Ёсць яшчэ адзін бок справы, на які, як нам здаецца, не варта забывацца, - навуковая этыка. Яна патрабуе абароны ісціны аб аўтарстве той ці іншай этымалагічнай версіi, яна патрабуе адвесці кожнаму даследчыку належнае месца адпаведна сапраўднай каштоўнасці яго заслуг (с. 23-24).

Гэтыя словы гучаць асабліва актуальна ў наш час, калі безумоўныя канстанты навуковай этыкі размываюцца ва ўсё большай ступені, калі бязмежныя іншы раз кампіляцыі і прамы плагіят, свядомае “забыццё” пастаноўкі двукоссяў і ўзгадвання аўтараў, татальная дэградацыя экспертнай дзейнасці пакрысе ўсталёўваюцца ў навуковай літаратуры, у тым ліку, зразумела, і ў этымалагічных даследаваннях, ледзь не ў якасці нормы.

У першым раздзеле праспекта “Агульныя палажэнні” дастаткова і іншых разважанняў Р. Краўчука, у прыватнасці, аб шматверсійнасці этымалагізавання, абмеркаванне пытанняў паўнаты прадстаўлення ў бібліяграфічнай частцы слоўнікавага артыкула высунутых версій, этымалагізавання запазычанняў, асабліва параўнальна новых і да т. п., аднак большасць 3 іх у прынцыпе добра вядомыя і не вартыя асаблівай рэфлексіі. Завяршаецца ён наступным заключэннем:

Выкладзены погляд на этымалагічны слоўнік, накіраваны на стварэнне дастаткова
поўнай па матэрыялу і надзейнай па метаду працы па лексіцы беларускай мовы,
не зможа засцерагчы работу ад некаторых пралікаў. З'явяцца пэўныя дапаўненні,
будуць удакладнены або адкінуты некаторыя версіі, будуць і істотныя ўдаскана-
лянні. Усё гэта з непазбежнасцю вынікае з самага характару этымалагізавання, якое
ў значнай ступені грунтуецца на меркаваннях, маючых большую або меншую сту-
пень верагоднасці (с. 31).

Другая частка праспекта “Спецыяльныя задачы этымалагічнага слоўніка беларускай мовы” амаль утрая меншая за першую, што цалкам апраўдана зразумелым звужэннем праблематыкі, якая абмяркоўваецца. Сцвярджаючы, што “беларускі этымалагічны слоўнік мае спецыфічную накіраванасць, якая выцякае з геаграфічнага становішча беларускай мовы, яе генетычных і гістарычных сувязей” (с. 31-32), аўтар пераходзіць да пастуліравання ідэі бе л а рускага этымалагічнага ландшафту іабгрунтавання яго асноўных складнікаў. Перш за ўсё, у агульным плане адзначаецца, што

кожная мова з этымалагічнага пункту погляду можа разглядацца як пэўны этымалагічны ладшафт. Гэты ландшафт фарміруецца і ўдакладняецца з ростам нашых ведаў пра лексіку данай мовы, пра яе паходжанне. Аднак у этымалагічным ландшафце не толькі адлюстроўваюцца нашы веды пра паходжанне слоў даследуемай мовы. Паняцце этымалагічнага ландшафту мае таксама і пэўную эўрыстычную каштоўнасць. [...] адным з элементаў этымалагічнага ландшафту з'яўляецца размеркаванне запазычанняў і субстратных уплываў у данай мове (с. 32).

Што ж тычыцца ўласна беларускага этымалагічнага ландшафту, то ён вывучаны пакуль недастаткова, таму 
даваць тут пэўныя “формулы”, якія ў радзе выпадкаў могуць быць прыведзены для рускай і ўкраінскай моў, было б цяжка. Аднак і тое, што мы ўжо ведаем пра размеркаванне беларускай лексікі, паказвае, што беларуская мова з'яўляецца вельмі цікавым этымалагічным ландшафтам, які заслугоўвае паглыбленага і уссебаковага вывучэння (там жа).

Галоўнымі складнікамі гэтага ландшафту ў дачыненні да задач ЭСБМ Р. Краўчук лічыць перш-наперш адлюстраванне ў слоўніку “лексічных узаемасувязей з суседнімі мовамі - рускай і ўкраінскай” (с. 33), далей 3 польскай, у непасрэдны кантакт з якой беларуская мова ўступае на захадзе (с. 34). Важнае месца адводзіцца лексіцы “ўскраінных і пераходных гаворак” з прычыны таго, што

ўскраінныя гаворкі параўнальна мала адчувальныя да інавацый, якія ідуць 3 цэнтральных арэалаў, таму ў іх часта захоўваюцца архаічныя рысы ${ }^{19}$, уключна і ў лексіцы. Пераходныя (змешаныя) гаворкі з прычыны сваёй адноснай ізаляванасці ад асноўных моў таксама захоўваюць у радзе выпадкаў вельмі старажытныя элементы (c. 36).

Вылучаюцца і асобныя зоны, актуальныя для ЭСБМ у арэальным плане: (a) усходняя з паласой смаленскіх гаворак, (б) паўночная/паўночна-заходняя 3 пераходам да пскоўскіх гаворак, в) заходняя, якая выяўляе сувязі с польскай мовай. Асобную ролю, на думку аўтара, маюць палескія гаворкі, якія з'яўляюцца "маргінальнымі, латеральнымі для ўсёй заходняй часткі ўсходнеславянскай моўнай тэрыторыі, г. зн. як для беларускай, так і для ўкраінскай моў”. Лексіка гэтых гаворак “павінна ў максімальнай ступені знайсці адлюстраванне ў этымалагічным слоўніку беларускай мовы” (там жа).

Узгадваецца, зразумела, таксама лексіка з неславянскіх моў, якая звязана з беларускай і павінна знайсці адлюстраванне ў ЭСБМ. Перш за ўсё, Р. Краўчук піша тут пра "размеркаванне ў беларускай мове балтызмаў, якія сустракаюцца не толькі ў зонах непасрэдных кантактаў з цяперашнімі балтамі” (с. 33), але адсылае чытача да наступнага раздзела, напісанага В. Мартынавым. Падрабязна, на трох старонках, спыняецца аўтар на германізмах, прычым заўважае наступнае:

становішча з вывучэннем нямецкіх элементаў у беларускй мове вельмі нездавальняючае. [Пры гэтым] ці не самай істотнай праблемай застаецца больш тонкі этымалагічны аналіз нямецкіх элементаў у славянскіх мовах, <што патрабуе> найбольш дакладна ўстанавіць дыялектную крыніцу (с. 38).

Шкада, што піянерская на той час20 ідэя вызначэння беларускага этымалагічнага ландшафту, якая належыць Р. Краўчуку, і цалкам удалая спроба

19 Тут падаецца наступная спасылка: “Гэта - адно з асноўных палажэнняў арэальнай лінгвістыкі” - $з$ далейшай апеляцыяй да (Bartoli 1925).

20 Узгадаем яшчэ раз, што асноўны тэкст праспекта, г. зн. часткі Р. Краўчука, напісаны ім у 1968-1969 гг., гл. вышэй. 
яго апісання, засталіся толькі ў неапублікаваным рукапісе праспекта ЭСБМ. Гэта істотна па прычыне таго, што гэта першынство ў гісторыі беларускай этымалогіі замацавалася за першым рэдактарам ЭСБМ В. Мартынавым.21

Праз вельмі кароткі час пасля стварэння Р. Краўчуком праспекта, менавіта ў 1972 г., В. Мартынаў апублікаваў артыкул "Беларуская этымалогія. Некаторыя аспекты”, дзе пісаў, што яе (этымалогіi) “бліжэйшая задача - вызначыць спецыфічны беларускі этымалагічны ландшафт” (Мартынаў 1972: 15). У тым самым годзе на міжнароднай сустрэчы славістаў - этымолагаў і гісторыкаў мовы - "Symposium zur etymologischen und historischen Erforschung des slawischen Wortschatzes", якая адбылася ў Лейпцыгу ў кастрычніку 1972 г., ён выступіў з дакладам “Белорусский этимологический ландшафт”.22 Варта жалю, але ніводнай згадкі пра высунутую літаральна нядаўна менавіта Р. Краўчуком ідэю ў яе даслоўнай дэфініцыі ні ў першым артыкуле, ні ў дакладзе, а потым і ў артыкуле па ім (Мартынов 1975), няма. Зразумела, і аргументацыя, і прыклады, і вызначаныя зоны “лексічнай кансервацыі” (усходнепалеская і паўночна-беларуская/віцебская), гл. таксама (Мартынаў 1978: 4), належаць выключна аўтару, ды і вызначэнне беларускі этылмалагічны ландшафт таксама ў пэўнай ступені ў тыя часы “ляжала на паверхні”, аднак усё ж такі нейкім чынам спаслацца на працу свайго калегі, няхай і неапублікаваную, было, бясспрэчна, па меншай меры пажаданым.

Дарэчы, што тычыцца прыгаданай вышэй трэцяй часткі праспекта "Пытанні беларускай этымалогіі і балта-славянская праблема”, якая была напісана В. Мартынавым, то яна, як падаецца, з'яўляецца ў працы адносна неабавязковай, больш таго - у пэўнай ступені чужароднай, таму што акрэслівае толькі адну, прычым, безумоўна, не першачарговую праблему, звязаную 3 пачаткам працы над ЭСБМ. Да таго ж нават у той час самае першае палажэнне, якое далей разгортвае аўтар: “Пры этымалагічным аналізе беларускай лексікі практычна вельмі часта даводзіцца мець на ўвазе магчымасць яе балтыйскага паходжання", - наўрад ці было абгрунтаваным у дастатковай ступені.23 Ёсць падставы лічыць, што гэтая частка была ўключана ў праспект пазней: якраз тады, калі Р. Краўчук быў вызвалены ад кіраўніцтва тэмай ЭСБМ, а на яго месца прызначаны загадчык сектара В. Мартынаў.24

21 Вось, напрыклад, што пісаў у 1978 г. адносна гэтага А. Трубачоў, спасылаючыся на артыкул (Мартынов 1975): “Лишь в самое последнее время раздаются [...] голоса о «белорусском этимологическом ландшафте»” (Трубачев 2004б: 365).

22 Фактычна рускамоўным клонам папярэдняга артыкула 1972 г.

23 Заўважым, што ва “Уводзінах" у 1-м томе слоўніка (Мартынаў 1978) гэтага занадта рэзкага, наўпрост безапеляцыйнага выказвання няма, аднак арыентацыя на пошук балтызмаў пры этымалагічным аналізе спрадвечнай беларускай лексікі ў значнай часткі слоўнікавых артыкулаў усё ж такі захавалася.

24 Менавіта аб гэтым сведчыць пачатак наступнага сказа ў кароткай прадмове да праспекта “Ад рэдактара” (гл. вышэй): “Рэдактар падзяляе думку аўтара...”, - што адназначна ўказвае на Р. Краўчука як адзін ага аўтара працы. 
Апошні раздзел працы “Пробныя артыкулы” ўтрымлівае на дзевяці старонках 39 слоўнікавых артыкулаў ад Абруд да Яna, частка якіх (да Лыч) у перапрацаваным аўтарам выглядзе ўвайшла ў першыя чатыры тамы ЭСБМ.

У заключэнне неабходна адзначыць, што публікацыя ў свой час праспекта, напісанага Р. Краўчуком, адыграла б, безумоўна, станоўчую ролю ў падрыхтоуцы першых тамоў “Этымалагічнага слоўніка беларускай мовы”, вызначэнні яго метадалагічнага апарату і рэпертуару сродкаў практычнай этымалагізацыі. Даводзіцца толькі шкадаваць, што гэтага не адбылося.

\section{ЛITAPATУРА}

Антропаў 2012 = Мікалай Антропаў, Праславянскія дыялектызмы ў “Этымалагічным слоўніку беларускай мовы”, в: Praslovanska dialektizacija v luči etimoloških raziskav: ob stoti obletnici rojstva akademika Franceta Bezlaja: zbornik referatov z mednarodnega znanstvenega simpozija v Ljubljani, 16.-18. septembra 2010, ur. Metka Furlan-Alenka Šivic-Dular, Ljubljana: Založba ZRC, ZRC SAZU, 2012, 25-32.

Антропов 2010 = Николай П. Антропов, На долгом пути к $Я$ (к 30-летию начала публикации “Этимологического словаря белорусского языка), Этимология 2006-2008, отв. ред. Ж. Ж. Варбот, Москва, 2010, 24-36.

Вступ 1966 = Вступ до порівняльно-історичного вивчення слов'янських мов, ред. О. С. Мельничук, Київ: Наукова думка, 1966.

Институт мовознавства 2005 = Інститут мовознавства ім. О. О. Потебні НАН України - 75: 1930-2005: матеріали до історії, відп. ред. В. Г. Скляренко, Київ: Довіра, 2005.

Кравчук 1955 = Рейнгольд В. Кравчук, Українські назви місяців, Украйнська мова в школі 3 (1955), 61-62.

Кравчук 1957 = Рейнгольд В. Кравчук, Етимології слів, Украйнська мова в школі 4 (1957), $79-82$.

Кравчук 1958а = Рейнгольд В. Кравчук, История суффиксов существительных в чешском языке: суффиксы с основным -к- (на материале памятников XIV-XVI в8.), Автореф. канд. дисс., Киев, 1958.

Кравчук 19586 = Рейнгольд В. Кравчук, Из истории чешской суффиксальной словообразовательной системы, Киев: Изд-во Акад. наук УССР, 1958.

Кравчук 1961 = Рейнгольд В. Кравчук, 3 історї слов'янського мовознавства: видатні славісти-мовознавиі, Київ: Рад. школа, 1961.

Кравчук 1968 = Рейнгольд В. Кравчук, [рец.:] J. В. Rudnyc'kyj. An etymological dictionary of the Ukrainian language (Parts 1-5), Winnipeg, 1966, Вопросы языкознания 4 (1968), 117-134.

лд = Личное дело: Кравчук Рейнгольд Владимирович, начато 7.08.1963, окончено 15.05.1989, Центральный научный архив НАН Беларуси, фонд 2, опись 1, № 20772, л. 1-53.

Лукінова - Півторак 2005 = Тетяна Б. Лукінова - Григорій П. Півторак, Славістичні студії, Институт мовознавства 2005, 72-112.

Лучыц-Федарэц 2010 = Іван І. Лучыц-Федарэц, Рэйнгольд Уладзіміравіч Краўчук, Беларуская лінгвістыка 64 (2010), 153-156.

Мартынаў 1972 = Віктар У. Мартынаў, Беларуская этымалогія: некаторыя аспекты, Беларуская лінгвістыка 1 (1972), 15-20.

Мартынов 1973 = Виктор В. Мартынов, Праславянская и балто-славянская суффиксальная деривачия имен, Минск: Наука и техника, 1973 [VII Международный съезд славистов: доклады]; 2-е выд.: Беларуская мовазнаўчая славістыка на з'ездах славістай, адк. рэд. М. П. Антропаў, Мінск: Беларус. навука, 2013, 67-109.

Мартынов 1975 = Виктор В. Мартынов, Белорусский этимологический ландшафт, Slawische Wortstudien: Sammelband des internationalen Symposiums zur etymologischen und historischen 
Erforschung des slawischen Wortschatzes, Leipzig, 11.-13. 10. 1972, Bautzen: Domovina-Verlag, $1975,60-69$.

Мартынаў 1978 = Віктар У. Мартынаў, Уводзіны, Этымалагічны слоўнік беларускай мовы 1 : $A-5$, Мінск: Навука і тэхніка, 1978, 3-16.

Трубачев 2004a = Олег Н. Трубачев, Задачи этимологических исследований в области славянских языков, в: Олег Н. Трубачев, Труды по этимологии: слово - история - культура 1, Москва, 2004, 25-35 [першая публікацыя - 1961 г.].

трубачев 20046 = Олег Н. Трубачев, Этимологические исследования восточнославянских языков: словари, в: Олег Н. Трубачев, Труды по этимологии: слово - история - культура 1, Москва, 2004, 365-378 [першая публікацыя - 1978 г.].

Цыхун 2012 = Генадзь Цыхун, Эксклюзіўныя міжславянскія ізалексы і праславянская арэальная структура, в: Praslovanska dialektizacija v luči etimoloških raziskav: ob stoti obletnici rojstva akademika Franceta Bezlaja: zbornik referatov z mednarodnega znanstvenega simpozija v Ljubljani, 16.-18. septembra 2010, ur. Metka Furlan - Alenka Šivic-Dular, Ljubljana: Založba ZRC, ZRC SAZU, 2012, 61-68.

Bartoli 1925 = Matteo G. Bartoli, Introduzione alla neolinguistica (principi - scopi - metodi), Genève: L. S. Olschki, 1925.

\section{PovZETEK}

\section{Stran iz zgodovine beloruske etimologije: koncept Rejngolda}

\section{Kravčuka}

V zgodovini izdelave Etimološkega slovarja beloruskega jezika (ESBM) je malo znana stran, povezana z imenom znanega ukrajinskega in beloruskega slavista in etimologa, enega od avtorjev prvih zvezkov slovarja - Rejngolda Kravčuka. Po prihodu iz Kijeva v Minsk leta 1963 za delo pri ESBM je nekako v letih 1968-1969 pripravil obsežen koncept slovarja, ki pa ni bil objavljen. Rokopis obsega štiri dele: Splošni položaj, Posebne naloge beloruskega etimološkega slovarja, Poskusne članke (razdelki R. Kravčuka), razdelek Vprašanja beloruske etimologije in baltoslovanski problem je napisal urednik koncepta V. Martynav. Tekstološka analiza kaže, da se je zadnji razdelek (načelno neobvezen) pojavil v konceptu nekoliko pozneje, namreč v letih 1972-1973. V članku so analizirani navedeni razdelki dela, metodologija, ki se predlaga za bodoči slovar glede na stvarno prakso njegove izdelave. Obravnavano je vprašanje avtorstva oznake beloruska etimološka pokrajina, kakršno je prvič predložil in utemeljil R. Kravčuk v neobjavljenem konceptu. 